No epistocracy without representation? The case of the European Central

\title{
Bank
}

Christopher Lord

ARENA Centre for European Studies, University of Oslo, Oslo, Norway

christopher.lord@arena.uio.no 


\section{No epistocracy without representation? The case of the European Central}

\section{Bank}

I argue the European Central Bank shows how mutually defining are i) the epistemic assumptions of independent central banking; ii) the powers of a central bank; iii) the political order in which it operates and iv) representative claims. I identify three 'representative turns' whose effects have cumulated over the history of the ECB: the first towards including representative claims in justifications for independent central banking; the second, towards a monetary dialogue between the ECB and the European Parliament; the third, towards providing the ECB with some means of discussing with parliaments how it should act in emergencies.

Keywords: Expert knowledge, Representation, European Central Bank, European and national parliaments.

Word count: 8250

\section{Introduction.}

It is often assumed that independent central banking simply removes an important area of policy-making from the process of mass political representation. The European Central Bank (ECB) provides an important case study of whether that assumption is justified. Given that the ECB is probably the most independent central bank in the developed world (European Parliament, 1998), any finding that even the ECB has been shaped by beliefs about representation, can be taken as a good indicator that independent central banking and representation are not necessarily opposites. Rather, they can be two more of the many attributes of contemporary government that co-evolve. I argue, that understandings of political representation have been fundamental to the ECB over the 20 years of its existence. Just as there can be no master without a slave and no slave without a master, the ECB shows how even strongly independent central banks have to define themselves in relation to the 
representative process; and how, on the other hand, representative institutions need to adjust to the powers and expertise of central banks.

The ECB is a good example of how mutually defining are i) the epistemic assumptions on which independent central banking is based; ii) the powers of a central bank; iii) the political order in which a central bank operates and, iv) claims about the best ways of delivering political representation. The ECB is an epistocratic institution or 'rule by knowers' (Estlund, 2008, p. 7, p. 209) in the sense that it is mandated to use its expert knowledge to make monetary policy independently of forms of political representation organised through the election of government and parliaments. Yet, the idea that independent central banks could have no relationship with governments and parliaments is probably practically absurd and normatively indefensible.

First, as will be shown here, independent central banks need to be embedded in overall processes of public justification, perhaps even more so than politically dependent ones. For sure, independent central banks could deliberate and consult with stakeholder groups or even representative panels of randomly chosen citizens. Yet parliaments remain unique forums of public justification. Only they are elected on a basis of 'one person, one vote' to represent publics in publicly visible deliberations with an encompassing oversight of all public matters (Habermas, 1996, p. 149). Second, independent central banks can only claim a public mandate if the public has some meaningful means of withdrawing that mandate. If, as John Stuart Mill put it, publics ought to have ultimate controlling power 'in its entirety' - or, if, as contemporary democratic theorists put it, publics ought to control all their policies and laws as equals - then even central banks must be included in the ultimate ability of publics to withdraw and redesign any powers by which they are governed. All this suggests obvious predicament. Independent central banks receive their mandates via elected governments and parliaments. Independent central banks need to justify their decisions in public dialogue with 
parliaments. Yet, independent central banking, of its nature, excludes certain kinds of relationship with governments and parliaments.

What does that predicament mean for the theme of this special issue? Namely, the idea that expert bodies may themselves need to make 'representative turns' by seeking relationships with representative institutions, particularly ones that can improve their legitimacy, credibility, visibility or even the knowledge need to function as epistocracies. The foregoing predicament suggests that independent central banks need to make representative turns both away and towards elected governments and parliaments: to form some relationships with them whilst avoiding others. Perhaps, if it is not stretching the metaphor too far, independent central banks may need to make representative pivots.

I argue that the ECB is the product of three pivots towards mass political representation. The effects of those pivots have cumulated across its history. The first pivot was already contained in general arguments for independent central banking that shaped the institutional design of the ECB. In claiming that monetary policy should be made independently of elected governments - and, therefore, of processes of political competition and electoral cycles - arguments for independent central banking clearly turned away from one very important understanding of representation: namely, the Schumpeterian (1942) and Schattsneidian (1960) assumption that the public is always best represented in proportion to how well the making of any public policy ultimately depends on a competition for the people's vote. But more was involved here than an attempt to carve out a monetary policy 'exception' from standard assumptions about political representation and competition. The case for independent central banking - of which the case for the ECB was so conspicuously a part (Gros \& Thygesen, 1998; Howarth \& Loedel, 2005; Issing, 2008; James, 2014) - was, as will be seen, based on strong representative and democratic claims of its own. 
The second was a turn towards a particular relationship between the ECB and the European Parliament (EP) that was only made possible by what was so unusual in developing independent central banking through the European Union's political order. Yet, that turn was not a simple adjustment of the ECB to the EU's political order and representative institutions. It was also an adjustment of the EP to the demands of holding a central bank to account. To oversee the ECB, a part of the EP had, in Weberian (1917/1994, pp. 176-177) fashion, to share somewhat in the expertise and work of the ECB. The EP itself had to develop some knowledge of independent central banking in order to sustain a 'monetary dialogue' on equal terms with the ECB.

The third was a turn, under the pressures of the euro-crisis, away from any assumption that the ECB merely represents some body of knowledge that can be employed largely without need for political judgement. That turn is incomplete at the time of writing. Yet it is plainly a loss of innocence in so far as it requires forms of representation that acknowledge just how unavoidably central banks do not merely use knowledge but exercise political power. Sections 2-4 describe and explain each of the foregoing representative turns. They demonstrate that the ECB has never been - and could never be - a pure form of 'rule of the knowers' (Estlund, 2008, p. 7). The ECB's powers have never been reducible to its knowledge; and its knowledge has never been sufficient to justify its powers. Representative claims have always been needed as additional premises in arguments that claim the ECB's powers are justified by its knowledge. The financial crisis has made more obvious the need for the ECB to be able to make representative claims if it is to justify those of its powers that do not really follow from its knowledge at all. 


\section{The first representative turn. Representative and other claims in arguments for independent central banking}

A standard argument for independent central banking is as follows; money is neutral. In other words, there is no enduring benefit from manipulating the quantity of money. Over the medium term, output and employment will be much where they would have been in the absence of any short-term monetary stimulus. The only thing that will be different is that inflation will be higher (Lucas, 1972). Whilst, however, the 'neutrality of money hypothesis' implies that altering the supply of money to achieve outcomes other than price stability is a pure welfare loss to voters, short-term manipulation of monetary policy can allow elected politicians to create an illusion of improved output and employment at the time of their reelection. Worse, since it is known that elected politicians can behave in this way, even honest politicians will be unable to achieve the best possible trade-offs between employment and growth on the one hand and inflation on the other (Kydland \& Prescott, 1977). Financial markets will demand higher interest rates - and workers will demand higher wages - to cover the risk that politicians might create surprise inflation during the course of a loan or a wage contract. Hence, transferring responsibility for monetary policy from elected politicians to an independent central bank does not just allow publics to achieve better combinations of lower inflation and higher growth and employment. It is the only way publics can achieve those outcomes.

As just summarised, the standard argument for independent central banking had important implications for what kind of 'rule by knowers' it was assumed the ECB would be. First, justifications for independent central banking were, in a sense, more motivational than epistemic. Even where they are politically controlled, central bankers can accumulate knowledge over time of optimal trade-offs between monetary (inflation) and real economic variables (growth and employment). Hence, independent central banking does not create the 
knowledge needed for optimal economic management. Rather, independent central banking removes motives - such as seeking re-election - that obstruct the best use of that knowledge.

Second, in so far as arguments for independent central banking were epistemic, those arguments often made assumptions about the overall nature of economic knowledge and the ways in which it is used by all actors, not just by central bankers. In particular, they assumed that - if not blessed of perfect rationality and foresight - market participants largely make best use of the knowledge available to them (efficient market hypothesis). On average the better informed economic actors and behaviours win out, until the economy performs more or less as it would have done with perfect knowledge. We will see later how that epistemic assumption made it seem easier than it really was to contain the ECB within a limited mandate.

Third, as already suggested, economic justifications for independent central banking also had to work as normative democratic arguments. Empirical assumptions about the motives and knowledge of bankers, markets and elected governments were only sufficient to justify independent central banking in combination with normative arguments about the rightness of delegating monetary policies away from day-to-day control by electoral or parliamentary majorities. Hence arguments for independent central banking had themselves to include democratic claims. One justification for delegating powers away from normal controls by electoral or governing majorities is that such delegations may be needed to safeguard the democratic process itself. Another justification is that the 'majority' is not, in any case, equivalent to the 'people'. The people may, in turn, only be able to secure certain values or outcomes - and govern themselves in the ways they want - where decisions are not controlled by particular political majorities (Rosanvallon, 2008, pp. 10-21). Independent central banking might fit both justifications. On the one hand, independent central banking removes an opportunity for governments to cheat on publics. Managing the economic cycle to 
fit the political cycle was assumed to be without any lasting benefit to the public. Given money was assumed to be neutral, any artificial stimulus would be without any long-term effect on growth and employment. Yet, the public would be left with higher inflation. It would also be exposed to risks of political manipulation by governments able to improve the chances of their own re-election by fooling publics into believing economic conditions are better than really are. On the other hand, the argument for independent central banking assumes, as seen, that independent control of monetary policy is the public's only chance of combining the lowest possible inflation (which is determined by the central bank) with underlying real growth in the economy (which is not determined by the central bank). So, to argue that a public cannot choose for itself to delegate to an independent central bank is to deny it its best chance of achieving an outcome - the lowest possible inflation consistent with any one rate of growth in income and employment - that is desirable from all points of view, except, perhaps those with an interest in writing down their debts at the expense of savers or those on those on fixed incomes.

Fourth, arguments for independent central banking made representative, as well as democratic claims. In other words, they were not just economic arguments that could also be used to make a democratic case for independent central banking. They also made more specific claims about which actors, in democracies, should best 'stand in for' the public - and how - in making monetary policy. Nor were those just negative representative claims that the public would be poorly represented in monetary decisions by those who depend on periodic competitions for the people's vote. Rather, the case for independent central bankers made at least two positive representative claims. First, that the public could be well represented in monetary decisions by selecting policy-makers (see Mansbridge (2009) for the 'selection model of representation) with known prior preferences, professional motivation and expertise. Second, that even if an independent central bank necessarily removed monetary decisions 
from the influence of elected representatives, the representation of the public in those decisions could, none the less, be fully secured through the central bank's mandate. In the case of the ECB, the argument was made, as follows, by its founding chief economist, Ottmar Issing (1999, pp. 508-509):

the more clearly and precisely the mandate is defined, the easier it will be to monitor the performance of the central bank. The more clearly and precisely the mandate is defined, the easier it will be in a democracy to justify the delegation of powers to an unelected body.

Whilst, though, it implied strong claims about structures and principles of representation, the economic argument for independent central banking in a sense assumed limited agency on the part of individual central bankers. They would use their knowledge within a mandate. The ECB would be a government of law based on the 'legitimacy of legality' (Scharpf, 2015, p. 392, p. 340. See also Joerges, 2014) and not 'of men'. Its decisions would follow from its mandate and from nothing but its mandate. It would need exercise no power that did not follow from its narrowly-defined responsibility under the treaties to ensure 'price stability'.

In sum, then, assumptions about democracy, representation and constitutionalism were all important to the empowerment of the ECB. It would be a democratically justified epistocracy and not just a ‘technical epistocracy' (Holst, 2011, pp. 6-7). Moreover, it would be a 'democratic-constitutional epistocracy'. The powers of the ECB would constitutionalise - within the hard-to-change treaties of the EU - a guarantee of the democratic process against political manipulation of monetary policy. The powers of the ECB would, then, themselves be constitutionally limited by the treaties to a narrowly defined responsibility for price stability. Indeed, the economic case for independent central banking assumed the ECB would be an unusually innocent form of economic constitutionalism. The normal objection that economic constitutionalism removes value-choices from the democratic political process would not apply. Since inexpert or electorally motivated monetary policy was assumed to change 
nothing in the real economy in the long-run, publics would not really give up value choices in choosing independent central banks. They would simply end up with less of a 'bad'; namely inflation. Nor would a second objection to economic constitutionalism apply; namely that it involves a kind of 'rule by ancestors' that locks subsequent cohorts of voters into economic institutions and policy choices that are hard to change. The ECB's mandate would, in a sense, be timeless: subsequent generations, and not just the present one, could be assumed to prefer an arrangement that simply promised lower inflation, given any one level of growth and employment that would, in any case, be determined exogenously to central banking.

\section{The second representative turn. The ECB and the European Parliament.}

Whilst, however, the embrace of independent central banking was universal to the democratic world from the 1970s, the empowerment of an independent central bank within the political order of the European Union was unique. The ECB is not the central bank of a single state. Rather it is the central bank of a multi-state, multi-national, multi-demos political order. By establishing a central bank within such a polity, the EU created an unusually independent central bank. It is important to understand that in detail, if we are also to identify a) what kind of 'rule by knowers' the ECB entails; b) how participation in the euro requires significant trust in the epistocratic claims of central bankers, and c) the responses available to representative institutions.

On the one hand, the ECB is unusually powerful and independent in comparison with other European Union institutions. As Kenneth Dyson (2000, p. 11) has remarked 'The ECB has the potential to play an active role as a supranational executive body that exceeds the autonomy of action available to the European Commission' (see also Hodson, 2011). Consider some ways in which Union institutions are normally constrained. First, powers are often distributed across several institutions. Most matters - and not just legislation - need to 
be more or less co-decided by several institutions under rules that require high levels of agreement within and across those institutions. Second, the Union, in any case, rarely enjoys its own exclusive competence in which it is free to decide what it wants without regard for what national and sub-national authorities are attempting to do in the same policy field. Sure, the Union claims that its laws take priority over any national measures that conflict with them. But that only leads on to the third constraint. The Union may claim primacy for its laws, but its decisions have to be implemented by national or sub-national authorities, over which the Union only has limited coercive resources.

In contrast, these constraints are weak in the case of the ECB. It acts in one of the few areas where the Union does have exclusive competence. Within the euro-zone it has monopoly control over monetary policy. Moreover, it decides monetary policy on its own initiative and without having to concern itself with any other veto holders amongst the other Union institutions. Finally, the ECB's implementing agents are not national governments, but national central banks, themselves part of the epistemic community of independent central banking; or, in other words, of those already subscribed to its empirical and normative assumptions. Moreover, national central bankers are themselves the dominant part of the ECB's governing Council.

Yet, the ECB does not just enjoy exceptional independence in comparison to other Union institutions. It also enjoys remarkable independence in comparison with other central banks. When the ECB started operating in 1998, the European Parliament (1998) described it as 'probably the most independent central bank' in the developed world. Rules for changing ECB powers are much more demanding than those for changing powers of a central bank within a single state political system. Being the central bank of 20 political systems (19 member states and the EU itself) with different electoral cycles also facilitates its 
independence. Given the ECB is exposed to the influence of 20 electoral cycles, it seems unlikely that its decisions will be dominated by any single electoral cycle.

However, the structure of the EU's political order does not just mean that the ECB is unusually independent. The structural features of the EU's political system have also allowed the ECB to form a relationship with the European Parliament of a kind an independent central bank would find hard to develop with the national parliament of most of the Union's member states. Herein lies the second representative turn: the ECB is not just the product of representative claims implicit in the economic case for independent central banking. It has also developed its own ways of justifying its decisions to elected representatives.

Terry Moe (1990, p. 143) once observed that it is possible to delegate powers to a public body and then spread out surveillance of that body between several other institutions and actors in such a way that 'no one controls the agency and yet the agency is controlled'. Moreover, dispersing controlling powers between multiple bodies each of which represents different majorities in different ways has many attractions in systems where any one majority only has a flimsy basis for representing the whole. As Pierre Rosanvallon (2008) puts it, a majority may only be a chance agglomeration of minorities rather than a 'general will': a majority at one particular moment, at one level of aggregation, and according to just one method of counting votes. In the case of the ECB multiple practical dependencies and reporting obligations could conceivably require it to justify itself and maintain the active cooperation of individual governments, the Commission, the Council of Ministers, the EP and national parliaments, and even the Court, without any one of those bodies being in a position to compromise the independence of the bank.

Whilst, though, the ECB without any doubt has many reasons for wanting to maintain the confidence and active co-operation of many different actors within the Union's dispersed institutional order, it has, in practice, privileged the EP as the forum in which it justifies its 
decisions in public to representatives of the public. The ECB has itself eagerly supported a monetary dialogue with the EP (Amtenbrink \& Van Duin, 2009, p. 570). Although the Treaty only requires an annual hearing, the ECB's founding President, Wim Duisenberg, agreed to hearings every third month with the EP. Three points are of note in the representative turn in the ECB's formative years towards the EP.

First, quite regardless of how far the ECB consciously articulated abstract normative standards of public justification, it needs to be understood just why it was so important for its legitimacy that the ECB should have turned to a parliamentary form of representation to provide public justification for its decisions. Arguments for independent central banking only imply that monetary policy should, as it were, be exempted from democratic politics as a form of political competition, not from democracy as a structure of justification. Arguments for independent central banking - such as 'time inconsistency' that make it hard to optimise policy over all time periods - only require the decoupling of monetary policy from electoral cycles. They hardly justify freeing central banks from the normal obligations in a democracy to justify decisions to the public. To the contrary, a public body that is not regularly reauthorised and controlled by a competition for the people's vote is all the more obliged to justify its decisions to the public.

Nor is it hard to discern what those obligations might be. Each individual - and each point of view - must presumably have an equal right to a justification, given that democracy is a relationship of political equality. Justifications must presumably take the form of "public reason' (Rawls, 1993, pp. 212-254). They must in, other words, be framed as interpretations of how the public as a whole can benefit from policy choices. They must not be purely based on partial interests or on the 'arbitrarium (the pleasure or whim) of decision-makers (Pettit, 1997, p. 55). Moreover, if they are to be the judges of the quality of justifications, the public or its representatives must be able to weigh those justifications in open public debate that puts 
no restrictions on arguments beyond what publics and representatives take to be standards of good arguments (Habermas, 2003, p. 107). Although it is essential that much public debate is open, spontaneous, and even 'wild' and 'anarchic' (Habermas, 1996, p. 307), it is no less important that some of it should be formally structured. Thus justification of public policies to parliaments has, as seen earlier, the advantage of being formally structured around bodies that are elected on a basis of universal and equal suffrage.

Second, the structure of the EU's political system allows the ECB to have a relationship with the EP of a kind many national central banks cannot easily have with national parliaments. Precisely, because there is no governing majority in the EP, the ECB can have what is termed a 'monetary dialogue' with the EP without coming under pressure orchestrated by a governing majority. For sure, ECB Presidents have also appeared before committees of national parliaments. Since, however, the ECB is mandated to deliver price stability for the Euro-zone as a whole, the EP - rather than national parliaments - remains the representative body most likely to evaluate justifications for ECB decisions in ways compatible with its mandate. As the ECB (2017) has put it;

Our monetary policy is for the euro area as a whole... a single monetary policy requires single accountability...This (also) ensures that everyone in Europe has the same opportunity to hold us to account through the same bodies, namely the EP, as complemented by judicial review by the Court of Justice of the European Union.

Third, any turn to EP as a forum for the public justification of ECB decisions depended also, of course, on the EP. As Fabian Amtenbrink (2002. p. 158) has put it, the value of a central bank justifying its decisions to a representative body depends on the quality of the 'questions asked' and not just the 'answers' given. Nor can policy decisions be made more authoritative by surviving 'trial by debate' (Manin, 1995) where parliaments are not themselves critical, informed and representative of diverse opinions. Perhaps in a hope of motivating effective internal participation and debate in its monetary dialogue with the ECB, the EP sought to 
embed the latter in an ambitious interpretation of its treaty rights. It billed its right to be consulted on the appointment of the executive board of the ECB as full 'confirmation proceedings'. Each nominee was required to fill in a written questionnaire and appear in person before the Economic and Monetary Affairs Committee of the Parliament (EMAC). A mechanism for requesting the withdrawal of nominees was also written into the EP's own rules of procedure.

Beginning with the 'confirmation proceedings' the EP sought to press the ECB into ever close specification of its targets, forecasts and policy rules. MEPs would then use the ECB's own previous statements as benchmarks to judge the ECB in each subsequent hearing. It was thus hoped that the ECB's relationship with the EP could be turned into a form of selfappraisal on the part of the Bank, made all the more devastating by the impossibility of dismissing it as a political interference, whose assumptions derived from anywhere else than the ECB's own independent central bankers themselves. It was finally made clear that grave or persistent failure to live up to the standards that the ECB had set itself would be grounds for the EP to use its treaty rights to request an unscheduled meeting with the EP. Such a move, the EP believed, would be publicly perceived as a 'summons' (see European Parliament, 1998, and Lord, 2003).

Still, to sustain a monetary dialogue, the EP has had to adapt to the ECB as well as vice vera. This has been easy to the extent the EP has the general character of a 'working parliament' (Kurunmäki, 2014; Tingsten, 1938). In other words, it often responds to the challenge of holding complex modern epistocracies and bureaucracies to account by seeking to share in the knowledge and work of those bodies. David Beetham (1985) has summarised the 'Weberian' concept of parliamentary oversight as follows: 'Since knowledge forms the major source of bureaucratic power' the opportunity for parliaments 'to share in the knowledge and expertise' on which technocratic bodies make decisions 'is necessary to 
controlling' those decisions 'effectively'. Hence, the EP has appointed a 'monetary expert panel' and commissioned briefing papers from outside experts (Amtenbrink \& Van Duin, 2009). A possible danger, though, is that overcoming asymmetries of information that favour the ECB may require the EP to acquire a knowledge of central banking that makes it more of an expert body than a representative body (see also Lord, 2018) in its monetary dialogue with the ECB. The monetary dialogue with the ECB may itself depend on a specialised division of labour within the parliament that means ECB decisions are rarely debated by all representatives representing all points of view

Much of the foregoing is also open to the objection that justification of ECB decisions to the EP is insufficient for parliamentary control without some means of sanctioning inadequate justifications. However, to reply to that objection, there is no reason why the need for a central bank to justify itself to representative bodies should not be an important ingredient of what we know central banks care about most, namely, their credibility. In a study of the US Federal Drug Agency, Daniel Carpenter (2010) shows how some institutions can be 'hugely influential' even though there is little other basis for that power than their reputation. Hence, they are deeply constrained to maintain that reputation, including, one supposes, by providing credible public justifications for their decisions to representative bodies. 


\section{The third representative turn. An end of innocence}

When the ECB started work in 1998, the leading economist Charles Goodhart advised the European Parliament that no central bank could make decisions that derived only from its knowledge. Even if the standard economic argument for independent central banking is correct in its claim that money affects nothing real in the long-run, a central bank would still have to make a number of judgements. The following are amongst them: is it better to respond to unexpected inflation with a short sharp tightening of policy, or in a gentler, but drawn-out way? Is the risk of inflation falling below its target as undesirable as the risk of it exceeding its target? Should a central bank alter monetary policy in response to particular prices that can affect the stability of entire financial systems- notably asset price-bubbles even where there is no danger of inflation overall? It is not hard to see how these questions can be matters of normative judgement and social preference. They require more than expertise.

Moreover, the institutional design of the ECB arguably does less than it could to pen the bank into largely knowledge-based decisions. Crucial here is the distinction between goal independence where central banks can define their own objectives, and operational independence where they can only decide how to achieve goals delegated to them by a democratic process (Rogoff, 1986). The ECB has near complete goal independence, and not just operational independence. The Treaty merely stipulates that the ECB shall achieve price stability. Otherwise it leaves all important questions in the specification of that goal to the ECB itself: notably, the level of inflation to be targeted, as well as the foregoing questions of whether over-shooting or under-shooting are equally undesirable, and of how quickly the euro area should return to the target in the event of deviations from it. Yet, any concern that the ECB might be more independent than necessary, or that it might unavoidably have to form 
social preferences and make normative judgements in employing its knowledge of monetary policy was, as seen, initially cushioned by the assumption the ECB would not make long-term trade-offs of value, and that its decisions would not, therefore, be lasting exercises of political power. That, as also seen, seemed to imply that it would be a rather innocent form of epistocracy.

It is, however, precisely the idea that the ECB can be an episodic and epiphenomenal power-holder - a power-holder that only exercises power as a temporary, marginal and largely unintended consequence of other judgements - that has been challenged by the crisis. Financial crises require central banks to be - and to be perceived as - discretionary powerholders that are comfortable enough in that role to be credible in it. The crisis, arguably, only become a crisis because the ECB had to wrestle with assuming powers to back-stop public debt for which it had neither an uncontested mandate nor inclination. As Paul de Grauwe (2013, pp. 164-165) has put it, 'probably the worst decision was made by the ECB early on in the crisis when it decided not to take on the responsibility of systematically providing liquidity to the government bond markets'. The crisis only stopped being a crisis when a new ECB President made the ultimate discretionary commitment to do 'whatever it takes' to save the euro. If a central bank can only guarantee a currency against self-fulfilling market panics where it is known to have unlimited ability to act as lender of last resort to (solvent) banks and buy key financial assets such as government bonds, then it will unavoidably have to make discretionary decisions. To be a firefighter, it has to follow the fire and not just its mandate. Indeed, the financial crisis forced the ECB into a power-holding role that went well beyond the use of its knowledge to deliver a mandate strictly confined to price stability. First, the ECB ended up making decisions that involved exercising the most fundamental of political powers: powers over who should be in government; powers over which member states democracies won out where they disagreed on reform of the Eurozone; powers over who 
should remain in the Eurozone, and on whose terms; and powers over property rights, the solvency of states, and the distribution of massive financial losses between citizens and financial institutions. Those powers grew as i) the ECB had to decide whether it was going to give or withhold liquidity from particular banks in particular member states; and ii) the ECB became a 'guarantor of public debt' (de Grauwe, 2016, p. 154) once it was conceded that it should buy bonds in the secondary market. The Irish, Italian, Greek and Spanish cases all illustrate this. By forcing Ireland to bail out its banks in 2009, rather than restructure them, the ECB determined that Irish taxpayers, rather than banks, would carry losses (Sandbu, 2015). By cutting off liquidity to Greece in 2015, the ECB resolved the stand-off between Greece and creditor member states in favour of the latter. Then, of course, there were the famous letters from ECB President Jean-Claude Trichet to the Prime Ministers of Italy (Berlusconi) and Spain (Zapatero). As Agustin Menéndez (2012, p. 59) puts it, the letters made 'explicit the kind of reforms the ECB regarded as necessary within days of it expanding its securities market programme to Spanish and Italian debt'. Yet, leaving aside whether the ECB arbitrarily dominated member states in any of these cases, it is questionable whether it ever avoid any need to make tough calls in a crisis. The ECB has a duty to publics to avoid losses on financial assets. It also needs to support the financial system without encouraging irresponsible risks by making it safer to take those risks (moral hazard).

Second, the crisis revealed a latent power-game between the ECB in its role as monetary policy-maker and the collective of Eurozone governments in their role as fiscal policy-makers. Any system of independent central banking divides responsibility for monetary and fiscal policy. That creates a continuum of possibilities between monetary policy dominated by fiscal policy and fiscal policy dominated by monetary policy (Sargent \& Wallace, 1981). Where a currency area lies on the continuum is not just a matter of its institutional design, but also of strategic interactions between monetary and fiscal/political 
authorities, which can try to push one another into unwanted policy outcomes (Henning, 2016). The euro-crisis was, arguably, deepened in its early stages, by a policy stand-off in which Eurozone governments tried to force the ECB into monetary accommodation and buying government debt, whilst the ECB tried to force Eurozone governments into fiscal consolidation and structural reforms (Henning, 2016).

Third, the crisis also underlined, how, even in making incremental changes (Salines, Gløckler, \& Truchlewski, 2012), the ECB ended up exercising significant powers over the life-chances of individual citizens as well as whole democracies (Högenauer \& Howarth, 2016). For example, the Zapatero letter indicated the ECB would support 'Spanish banks if and only if' (Stiglitz, 2016, p. 155) changes were made to labour market legislation. Yet, if in backstopping the financial system, the ECB influences such decisions as labour regulation, it follows, to paraphrase John Rawls (2003, pp. 5-8), that the ECB influences the overall structure of laws, public policies and opportunities under which people live their lives. Not to mention how 'fairly' that overall structure then 'hangs together' as an overall 'scheme of social co-operation' (Rawls, 2003, pp. 5-8).

So why has the ECB ended up exercising powers that go vastly beyond the initial idea that it would only need to exercise rather ephemeral and epiphenomenal powers over deviations from inflation targets? Understanding the answer to this question is essential to understanding what may now be required of a third representative turn in the development of the ECB. Recall the epistemic assumption that those market behaviours which make the most efficient use of economic knowledge will win out. That assumption was important in two ways to the idea that the ECB would not need to exercise powers or discretion beyond a mandate that was strictly limited to the short-term needs of inflation targeting. First, it was assumed any risks of fiscal indiscipline would be at least partially priced into the borrowing costs of individual governments responsible for any laxity. Second, it was believed that 
central banks only needed to be known to have a credible commitment to keeping 'inflation low' (de Grauwe, 2013, p. 157) for markets to have all the information they needed to ensure the stability of the overall financial system.

The first implied that the ECB would not need to discipline governments; the second that it would not need to supervise financial markets. The ECB could, to repeat, just get on with delivering its tightly circumscribed and politically-given mandate to keep inflation low. It would not need to exercise any further powers over anyone. The first, however, overlooked that one piece of information the markets might use very efficiently indeed was what turned out to be a completely accurate prediction that neither governments which issued too much debt, nor banks which bought too much debt, would be allowed to go bankrupt. Hence markets would not necessarily discipline governments into an optimum (or even a sustainable) mix between monetary and fiscal policy. The second ignored a simple epistemic reason why central banks have, historically, always had to assume a role in supervising financial systems. It is endemic to financial systems that they will - in the absence of sound regulation - end up producing 'booms and busts culminating in banking crises' (de Grauwe, 2013). This is for the very simple reason that the overall level of systemic risk is simply unknowable to any market participant.

All this suggests two requirements of any 'third representative turn' in the development of the ECB. First the public needs some means of securing through their representatives accounts and justifications for outcomes that are not directly attributable to the ECB alone, but arise, instead, from interactions between the ECB and the choices of other bodies. That is especially important in the case of the 'policy mix' between the ECB's monetary decisions and the aggregate of the fiscal policies of the Eurozone governments (Enderlein, 2006; Foresti, 2015, p. 533) as co-ordinated on the fiscal side by the Commission and Council through the European semester. Wim Buiter explains the difficulty; 
where communication, co-operation and co-ordination between the central bank' and budgetary authorities 'are seriously impaired, central bank independence can do more harm than good. The costs of non-co-operation are apt to be especially serious if the dominant macro-economic problem is unwanted deflation (2006, pp. 2-3).

Second, the ECB's role as an emergency decision-maker in abnormal times can only be uncontentious if, in normal times, it develops clearer norms with representative bodies for how it should extend liquidity or back-stop public debt. Not the least reason why the ECB may need to agree and define those standards is that the crisis has deflated its knowledge claims at the same time as demonstrating how its knowledge cannot, in any case, be sufficient to justify its powers. For sure, the ECB's Open Market Transactions (OMT) is credited with saving the Euro. Yet, the OMT - and many other decisions taken during the crisis - divided the bank's Governing Council. Before the crisis, the Governing Council took many decisions without voting at all (Issing, 2008, p. 153). Since the crisis it has been unable to make several decisions without taking votes, including votes that famously out-voted the Bundesbank (see interview with Jens Weidmann, president of the Deutsche Bundesbank, Frankfurter Allgemeine Zeitung 17 January 2018). That, of course, is a clear indicator that central banking is not based on a body of 'means-ends' knowledge that is so unproblematic that any two central bankers will mostly use it in the same way.

The two foregoing requirements suggest a 'third representative turn' may need to differ from the relationship the ECB has developed with the EP. Article 13 of the Fiscal Compact - now re-named the Treaty on Stability, Convergence and Growth - allows for conferences made up of the relevant committees of the European and national parliaments. Both norms of how the ECB should use emergency powers to provide liquidity and backstop debt - and oversight of the policy-mix between monetary and fiscal policy - would sensibly be deliberated within a 'parliamentary field' (Crum \& Fossum, 2009) of national and 
European Parliaments. Both involve an interplay between the individual and shared powers, interests and normative responsibilities, Eurozone democracies may have to one another.

\section{Conclusion}

I have argued that it has been difficult to define the ECB as a justifiable form of epistocracy without also specifying standards of political representation; standards of how the ECB should relate to elected representative institutions and of how it should itself represent the public in making monetary decisions. From the start the case for independent central banking involved both positive and negative representative claims. Positive representative claims that the ECB decision-makers could be selected and mandated in ways that would hold it to strong representative standards. Negative representative claims that optimal monetary policy could not be delivered by systems of representation that rest on periodic competitions for the people's vote. From that it seemed to follow electoral representation could itself be improved by constitutionalising monetary policy so that it could not be used to cheat on voters by artificially manipulating the economic cycle to fit the political cycle. However, exempting central banks from normal processes of political competition cannot be an argument for exempting them from normal standards of public justification in a democracy. Hence, as a second representative turn, the ECB itself supported a strong 'monetary dialogue' with the European Parliament. Yet a dialogue with the EP on how it should use its mandate cannot be enough to justify the discretion, judgement and powers beyond its mandate that the ECB exercised during the crisis over national democracies and their citizens. Thus, as a third representative turn, the ECB may need to work out with representatives of national parliaments as well as the EP standards for regulating 'policy mixes' between the European and national levels, as well as norms that are fair between national democracies for how the ECB should provide emergency liquidity and backstop public debt. 


\section{References}

Amtenbrink, F. (2002). On the legitimacy and democratic Accountability of the European Central Bank: legal arrangements and practical experiences. In A. Arnull \& D. Wincott (Eds.), Accountability and legitimacy in the European Union. Oxford: Oxford University Press, 147-163.

Amtenbrink, F., \& van Duin, K. (2009). The European Central Bank before the European Parliament. Theory and practice after ten years of monetary dialogue. European Law Review, 34(4), 561-583.

Beetham, D. (1985). Max Weber and the theory of modern politics. Cambridge: Polity Press.

Buiter, W. (2006). The sense and nonsense of Maastricht revisited: what have we learned about stabilization in Monetary Union? Journal of Common Market Studies, 44(3), 687-710.

Carpenter, D. (2010). Reputation and power. Organizational image and pharmaceutical regulation at the FDA. Princeton: Princeton University Press.

Crum, B., \& Fossum, J.-E. (2009). The multilevel parliamentary field. A framework for theorising representative democracy in the EU. European Political Science Review, $1(2), 249-271$.

Dyson, K. (2000). The politics of the Euro-Zone, stability or breakdown? Oxford: Oxford University Press.

Enderlein, H. (2006). The Euro and political union. Do economic spillovers from monetary integration affect the legitimacy of EMU? Journal of European Public Policy, 13(7), 1133-1146.

Estl, D. (2008). Democratic authority, a philosophical framework. Princeton: Princeton University Press.

European Central Bank (2017, March 30). Keynote address by Y. Mersch, member of the 
Executive Board at the Symposium on Building the Financial System of the Twentyfirst century, Frankfurt Am Main. Retrieved from www.ecb.europa.eu.

European Parliament (1998). Resolution on democratic accountability in the third phase of EMU (The Randzio-Plath report). Brussels: European Parliament.

Foresti, P. (2015). Monetary and debt-concerned fiscal policies interactions in monetary unions. Journal of International Economics and Economic Policy, 12(3), 541-552.

Grauwe de, P. (2013). The political economy of the Euro. Annual Review of Political Science, 16, 153-170.

Grauwe de, P. (2016). The Legacy of the Eurozone crisis and how to overcome it. Journal of Empirical Finance, 39 (B), 147-155.

Gros, D. \&, Thygesen, N. (1998). European Monetary Integration. Harlow: Addison, Wesley, Longman.

Habermas, J. (1996). Between facts and norms. Cambridge: Polity.

Henning, R. C. (2016). The ECB as a strategic actor. Central banking in a politically fragmented monetary union. In J. Caporoso \& M. Rhodes (eds), The political and economic dynamics of the Eurozone crisis (pp.167-199). Oxford: Oxford University Press.

Hodson, D. (2011). Governing the Euro Area in good times and bad. Oxford: Oxford University Press.

Holst, C. (2011, October 20-22). Epistocracy, conceptual clarifications. Paper presented to workshop on 'Epistemic Democracy in Practice', Yale University.

Howarth, D., \& Loedl. P. (2005). The European Central Bank, the new European leviathan. Basingstoke: Palgrave.

Högenauer, A.-L., \& Howarth, D., (2016). Unconventional monetary policies and the European Central Bank's problematic democratic legitimacy. Journal of Public Law 17(2), 1-24. 
Issing, O. (1999). The Eurosystem, transparent and accountable or 'Willem in Euroland.' Journal of Common Market Studies, 37(3), 503-519.

Issing, O. (2008). The birth of the Euro. Cambridge: Cambridge University Press.

James, H. (2014). Making the European Monetary Union. Harvard: Belknap Press.

Joerges, C. (2014). Brother, can you paradigm? International Journal of Constitutional Law, 12 (3), 769-785.

Kurunmäki, J. (2014). Rhetoric against rhetoric. Swedish parliamentarianism and the interwar crisis of democracy. In K. Palonen, J.M.Rosales \& T.Turkka (Eds.), The parliamentary politics of dissensus. Parliament in debate (pp. 171-202). Santander: Cantabria University Press and McGraw Hill Interamericana de Espána.

Kydland, F., \& Prescott, E. (1977). Rules rather than discretion, the inconsistency of optimal plans. Journal of Political Economy, 85(3), 473-492.

Lord, C. (2003). The European Parliament in the economic governance of the EU. Journal of Common Market Studies, 41(2), 249-267.

Lord, C. (2018). The European Parliament. A working parliament without a public? Journal of Legislative Studies, 24(1), 34-50.

Lucas, R. (1972). Expectations and the neutrality of money. Journal of Economic Theory, 4 (1), 103-124.

Manin, B. (1995). Principes du Gouvernement Représentatif [Principles of representative government]. Paris: Calman-Lévy.

Mansbridge, J. (2009). A 'selection model' of political representation. Journal of Political Philosophy, 17(4), 369-398.

Menéndez, A. (2012, May 15). European Crisis. Paper Presented to ARENA seminar. ARENA Centre for European studies, Oslo.

Moe, T. (1990). Political institutions: the neglected side of the story. Journal of Law, 
Economics and Organisation, 6, 213-253.

Pettit, P. (1997). Republicanism: a theory of freedom and government. Oxford: Oxford University Press.

Rawls, J. (1993). Political liberalism. New York: Columbia University Press

Rawls, J. (2003). Justice as fairness. A restatement. Harvard Mass: Belknap Press.

Rogoff, K. (1985). The optimal degree of commitment to an intermediate monetary target. Quarterly Journal of Economics, 100(4), 1169-1189.

Rosanvallon, P. (2008). La légitimité démocratique: impartialité, réflexivité, proximité [Democratic legitimacy : impartiality, reflexivity, proximity]. Paris: Seuil.

Salines, M., Gløckler, G., \& Truchlewski, Z. (2012). Existential crisis, incremental response: the Eurozone's dual institutional Evolution. The Journal of European Public Policy 19(5), 665-681.

Sandbu, M. (2015). Europe's orphan, the future of the Euro and the politics of debt. Princeton: Princeton University Press.

Sargent, T., \& Wallace, N. (1981). Some unpleasant monetarist arithmetic. Federal Reserve Bank of Minneapolis Quarterly Review, 5(3), 1-18.

Scharpf, F. (2015). After the Crash. A Perspective on European Multi-level Democracy. European Law Journal 21 (3), 384-405.

Schattsneider, E. (1960). The semi-sovereign people: a realist's view of democracy in America. New York: Holt.

Schumpeter, J. (1942). Capitalism, socialism and democracy. New York: Harper.

Stiglitz, J. (2016). The Euro and its threat to the future of Europe. London: Allen Lane.

Tingsten, H. (1938). Nordisk Demokrati. Nordens kalender, 9, 41-50.

Weber, M. (1917/1994). Parliament and government in Germany under a new political 
Order. In P. Lassman \& R. Speirs (Eds.), Weber: political writings (pp. 130-271).

Cambridge, Cambridge University Press. 